\title{
Systemic Review: Is an Intradiscal Injection of Platelet-Rich Plasma for Lumbar Disc Degeneration Effective?
}

Takashi Hirase ${ }^{1}$, Robert A. Jack II II ${ }^{1}$, Kyle R. Sochacki ${ }^{1}$, Joshua D. Harris ${ }^{1}$, Bradley K. Weiner ${ }^{1}$

1. Orthopedics and Sports Medicine, Houston Methodist Hospital, Houston, USA

Corresponding author: Takashi Hirase, thirase@houstonmethodist.org

\begin{abstract}
Current studies evaluating the outcomes of intradiscal platelet-rich plasma (PRP) injections in degenerative disc disease (DDD) are limited. The purpose of this review was to determine if an intradiscal injection of PRP for degenerative discs results in a statistically significant improvement in clinical outcomes. A systematic review was performed using Preferred Reporting Items for Systematic Reviews and Meta-Analyses (PRISMA) guidelines. Level I-IV investigations of intradiscal PRP injections in DDD were sought in multiple databases. The Modified Coleman Methodology Score (MCMS) was used to analyze the methodological quality of the study. Only the outcome measurements used by more than $50 \%$ of the studies were included in the data analysis. The study heterogeneity and nature of evidence (mostly retrospective, non-comparative) precluded meta-analysis. Pre and post-injection pain visual analog scales (VAS) were compared using two sample Ztests. Five articles (90 subjects, mean age $43.6 \pm 7.7$ years, mean follow-up $8.0 \pm 3.6$ months) were analyzed. Four articles were level IV evidence and one article was level II. Mean MCMS was $56.0 \pm 10.3$. There were 43 males and 37 females (10 unidentified). Pain VAS significantly improved following lumbar intradiscal PRP injection ( $69.7 \mathrm{~mm}$ to $43.3 \mathrm{~mm}$; $\mathrm{p}<0.01)$. Two patients $(2.2 \%)$ experienced lower extremity paresthesia after treatment. One patient (1.1\%) underwent re-injection. No other complications were reported. In conclusion, intradiscal injection of PRP for degenerative discs resulted in statistically significant improvement in VAS with low re-injection and complication rates in this systematic review. It is unclear whether the improvements were clinically significant given the available evidence. The low level of evidence available (level IV) does not allow for valid conclusions regarding efficacy; however, the positive results suggest that further higher-quality studies might be of value.
\end{abstract}

Received 06/09/2020

Review began 06/20/2020 Review ended 06/21/2020 Published 06/25/2020

๑) Copyright 2020

Hirase et al. This is an open access article distributed under the terms of the Creative Commons Attribution License CC-BY 4.0., which permits unrestricted use, distribution, and reproduction in any medium, provided the original author and source are credited.
Categories: Pain Management, Neurosurgery, Orthopedics

Keywords: platelet-rich plasma, degenerative disc disease, intradiscal injection

\section{Introduction And Background}

Low back pain (LBP) is one of the most common causes of disability in the United States, with over $80 \%$ of American adults experiencing one or more lifetime episodes [1-2]. Although various organic and inorganic pathologies may cause LBP, degenerative disc disease (DDD) accounts for more than $40 \%$ of chronic LBP in the United States [3-4]. In spite of the high prevalence and morbidity associated with DDD, current treatment options are limited. Common treatments of early disease consist of a combination of conservative measures, such as bed rest, non-steroidal anti-inflammatory drugs (NSAIDs), physical therapy, and analgesic injections, which have shown to decrease symptoms but do not slow the progression of the disease [5-8]. Treatment of later disease consists of surgical approaches, including discectomy and spinal fusion, which are invasive, expensive, and have high rates of postoperative complications [9-13].

In recent years, platelet-rich plasma (PRP) has emerged as a relatively non-invasive treatment option for DDD unresponsive to conservative measures [14]. PRP is an autologous concentrate of various cells and growth factors acquired from centrifuged whole blood with growing evidence of its application in the healing response across different specialties, particularly in orthopedics. PRP has been shown to achieve its effects by delivering a high concentration of growth factors, including transforming growth factor- $\beta$, insulin-like growth factor, platelet-derived growth factor, and vascular endothelial growth factor, which activate cell proliferation and differentiation of vascularized cells [15]. Thus, various studies indicate its effective application in areas where vascularity is relatively preserved, including ligament, tendon, and muscle pathologies such as osteoarthritis, tendinopathies, lateral epicondylitis, and muscular injuries [1617]. On the other hand, the vascular supply to the human intervertebral disc recedes completely during the developmental process, leaving virtually no direct blood supply to the disc in a healthy adult [18]. Therefore, it may be hypothesized that growth factors will have minimal effect on the degenerated discs. However, PRP has also demonstrated to have an anti-inflammatory effect by decreasing pro-inflammatory mediators at the injected site primarily by reducing the transactivation of the inflammatory regulator, nuclear factor-kappa $\mathrm{B}$, and by inhibiting the inflammatory enzymes cyclooxygenase 2 and 4, metalloproteinases, and disintegrins [19-21]. This latter effect of PRP makes it a potential injectable option for the management of discogenic pain in DDD. 
Current studies evaluating the outcomes of intradiscal PRP injections in DDD are mostly limited to small case reports and retrospective studies. Thus, the purpose of this investigation was to determine if the intradiscal injection of PRP for DDD results in statistically significant improvement in clinical outcomes with low re-injection and complication rates. The authors hypothesized that the procedure results in statistically significant improvement in pain VAS with low re-injection and complication rates.

\section{Review}

\section{Methods}

A systematic review was registered with PROSPERO (International Prospective Register of Systematic Reviews) on August 31, 2017 (Registration \# CRD42017075843). PRISMA guidelines were followed [22]. Eligible studies consisted of level I-IV (via Oxford Centre for Evidence-Based Medicine (CEBM)) therapeutic studies that investigated the outcomes of intradiscal PRP injections for lumbar DDD among adult human patients [23]. The diagnosis was made in each included study based on a combination of history, physical examination, and radiographs, including magnetic resonance imaging (MRI) for every patient. Studies that included non-DDD etiology of back pain were excluded. Cadaveric studies, basic science and animal studies, diagnostic studies, economic studies, prognostic studies, level V evidence expert opinions, letters to editors, and review articles were excluded. Studies published in non-English languages were not excluded but were unidentified in the medical databases. In the event of different studies with duplicate subject populations, the study with the longer follow-up, higher level of evidence, greater number of subjects, or greater clarity of methods and results was included. The authors conducted separate searches of the following medical databases: MEDLINE, Web of Science, and Cochrane Central Register of Controlled Trials databases. Under the PROSPERO registration, similar prior systematic reviews and meta-analyses were sought and none were identified. The searches were performed on April 20, 2020. The search terms used were "platelet-rich plasma," "degenerative disc," "spine," and "injection." The search results were reviewed for duplicates and the inclusion criteria to determine articles that were included in the final analysis (Figure 1).

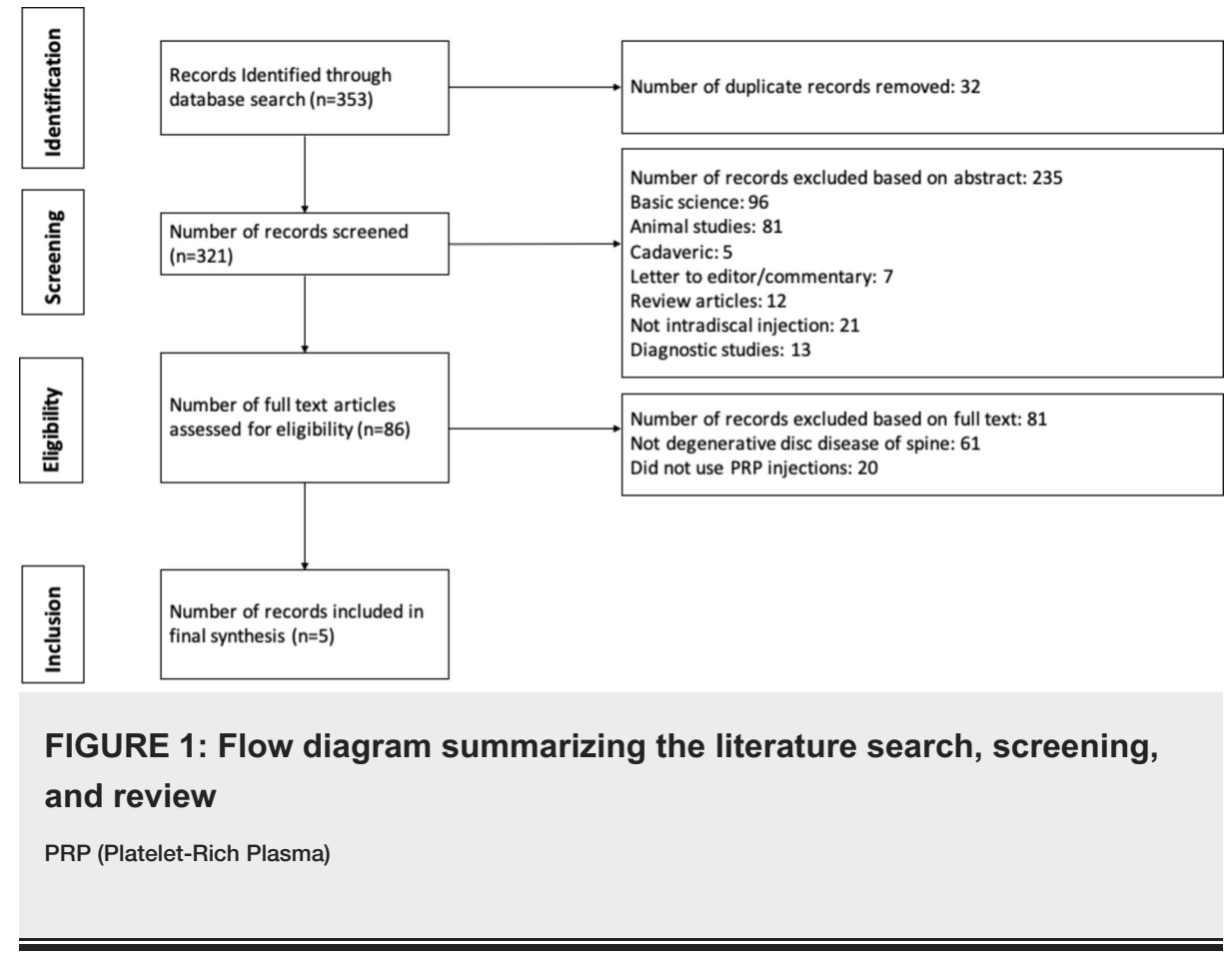

Two authors independently reviewed all articles using the methodology recommended by Harris et al. [24]. The study design, patient populations, and procedure technique were first identified. All lower back-specific patient-reported outcome scores, re-injection rates, and complication rates were analyzed.

The levels of evidence were then assigned based on the Oxford Centre for Evidence-Based Medicine [23]. Study methodological quality was analyzed using the Modified Coleman Methodology Score (MCMS) [25]. The overall Strength-of-Recommendation Taxonomy (SORT) score was B and Grading of Recommendations Assessment, Development, and Evaluation (GRADE) score was C [26-27]. Study heterogeneity and nature of evidence (mostly retrospective, non-comparative) precluded meta-analysis. Thus, a best-evidence synthesis was used instead [28]. Only the outcome measurements used by more than $50 \%$ of the studies were included in the data synthesis to increase the power of the measurement over that of individual studies. A weighted mean of pre- and post-injection values from each study was calculated and comparisons were made using two sample Z-tests (http://in-silico.net/tools/statistics/ztest) using a p-value of less than 0.05 for significance. The individual changes in LBP visual analog scale (VAS) were compared with a previously 


\section{Cureus}

reported minimal clinically important difference (MCID) of 22.5 , substantial clinical benefit (SCB) of 32.5 , and a patient acceptable symptomatic state (PASS) of 33.5 [29-30].

\section{Results}

Five articles were analyzed (Table 1) [31-35]. Four articles were level IV evidence and one article was level II. According to MCMS, one article was good (scores between 70 to 84), three articles were fair (scores between 55 to 69 ), and one article was poor (scores less than 55). The mean MCMS was $56.0 \pm 10.3$. There were 90 patients analyzed. There were 43 males and 37 females (10 unidentified). The mean age was $43.6 \pm 7.7$ years old with a mean follow-up of $8.0 \pm 3.6$ months.

\begin{tabular}{|c|c|c|c|c|c|}
\hline Study & Tuakli et al. 2016 [31] & $\begin{array}{l}\text { Comella et al. } 2017 \\
\text { [32] }\end{array}$ & Akeda et al. 2017 [33] & Levi et al. 2016 [34] & Bhatia et al. 2016 [35] \\
\hline Type of study & $\begin{array}{l}\text { Prospective, double- } \\
\text { blind randomized } \\
\text { controlled study }\end{array}$ & Case Series & Case Series & Case Series & Case Series \\
\hline $\begin{array}{l}\text { Level of } \\
\text { evidence }\end{array}$ & II & IV & IV & IV & IV \\
\hline No. subjects & 29 & 15 & 14 & 22 & 10 \\
\hline Gender (M/F) & $14 / 15$ & $11 / 4$ & $8 / 6$ & 10/12 & NR \\
\hline $\begin{array}{l}\text { Age }(\text { mean, } \\
\text { years) }\end{array}$ & 41.4 & 51.5 & 33.8 & 47.5 & $N R$ \\
\hline $\begin{array}{l}\text { Injection } \\
\text { method }\end{array}$ & $\begin{array}{l}\text { Fluoroscopy-guided } \\
\text { single injection of } \\
\text { autologous PRP into } \\
\text { one or more } \\
\text { symptomatic } \\
\text { degenerative IVD }\end{array}$ & $\begin{array}{l}\text { Fluoroscopy-guided } \\
\text { injection of } 1 \mathrm{ml} \text { of } \\
\text { SVF/PRP suspension } \\
\text { into one or more } \\
\text { symptomatic IVD }\end{array}$ & $\begin{array}{l}\text { Fluoroscopy-guided } \\
\text { single injection of } \\
\text { autologous PRP into } \\
\text { one or more } \\
\text { symptomatic } \\
\text { degenerative IVD }\end{array}$ & $\begin{array}{l}\text { Fluoroscopy-guided } \\
\text { single injection of } \\
\text { autologous PRP into } \\
\text { one or more } \\
\text { symptomatic } \\
\text { degenerative IVD }\end{array}$ & $\begin{array}{l}\text { Single injection of } 5 \mathrm{~mL} \\
\text { autologous PRP into } \\
\text { epidural space via } \\
\text { interlaminar approach } \\
\text { w/ } 18 \mathrm{G} \text { needle }\end{array}$ \\
\hline $\begin{array}{l}\text { Follow-up } \\
\text { (months) }\end{array}$ & 12 & 6 & 10 & 6 & 3 \\
\hline Outcomes & $\begin{array}{l}\text { VAS, FRI, SF-36 pain, } \\
\text { SF-36 physical function }\end{array}$ & VAS, PPI, ODI & VAS, RDQ & VAS, ODI & VAS, MODQ \\
\hline $\begin{array}{l}\text { Post-injection } \\
\text { treatments }\end{array}$ & No & No & No & No & No \\
\hline $\begin{array}{l}\text { Post-injection } \\
\text { cryotherapy }\end{array}$ & No & No & No & No & No \\
\hline $\begin{array}{l}\text { Use of NSAIDs } \\
\text { (few days pre- } \\
\text { injection and } \\
\text { immediate } \\
\text { post-injection) }\end{array}$ & No & No & $\begin{array}{l}\text { Yes - post-injection for } \\
\text { unbearable pain }\end{array}$ & No & No \\
\hline
\end{tabular}

\section{TABLE 1: Study demographics}

NR (Not Recorded); PRP (Platelet-Rich Plasma); IVD (Intervertebral Discs); FRI (Functional Rating Index); SF-36 (36-item Short-Form Health Survey); VAS (Visual Analog Score); PPI (Present Pain Intensity); ODI (Oswestry Disability Index); RDQ (Roland-Morris Disability Questionnaire); MODQ (Modified Oswestry Disability Questionnaire); SVF: Stromal Vascular Fraction; RDQ: Roland-Morris Disability Questionnaire

PRP was obtained in all studies by the centrifugation of 30 to $200 \mathrm{~mL}$ of autologous blood to perform a fluoroscopy-guided injection of 1 to $5 \mathrm{~mL}$ of PRP directly into one or more symptomatic lumbar intervertebral discs (Table 2). Three studies confirmed symptomatic discs using provocative discography. The remaining two studies utilized MRI alone with a combination of history and physical exam. All studies performed intradiscal PRP injections after the failure of non-interventional management. None of the studies recorded the use of post-injection cryotherapy. One study approved the use of post-injection NSAIDs for unbearable pain. No study compared leukocyte-poor PRP to leukocyte rich PRP. However, one study reported using leukocyte-poor PRP, and one study reported using leukocyte-rich PRP. One study used 


\section{Cureus}

\begin{tabular}{|c|c|c|c|c|c|}
\hline Study & Tuakli et al. 2016 [31] & $\begin{array}{l}\text { Comella et } \\
\text { al. } 2017 \text { [32] }\end{array}$ & Akeda et al. 2017 [33] & Levi et al. 2016 [34] & $\begin{array}{l}\text { Bhatia et al. } \\
2016 \text { [35] }\end{array}$ \\
\hline $\begin{array}{l}\text { PRP Spinning } \\
\text { Approach }\end{array}$ & NR & Single & Double & Single & $\mathrm{NR}$ \\
\hline $\begin{array}{l}\text { Duration of } \\
\text { Spin (Minutes) }\end{array}$ & $\mathrm{NR}$ & 8 & 15 and 15 & 14 & $\mathrm{NR}$ \\
\hline Company & $\begin{array}{l}\text { Harvest Technologies } \\
\text { Corporation, Plymouth, MA, USA }\end{array}$ & $N R$ & $\begin{array}{l}\text { Kawasumi Laboratories, } \\
\text { Inc., Tokyo, Japan }\end{array}$ & $\begin{array}{l}\text { Harvest Technologies } \\
\text { Corporation, Plymouth, MA, USA }\end{array}$ & NR \\
\hline PRP Activator & NR & NR & $\mathrm{CaCl}_{2}$ & NR & NR \\
\hline $\begin{array}{l}\text { PRP Volume } \\
\text { Injected (ml) }\end{array}$ & $1-2$ & 1 & 2 & 3 & 5 \\
\hline $\begin{array}{l}\text { Platelet } \\
\text { Concentration }\end{array}$ & NR & NR & $3.7 \mathrm{x}$ baseline & NR & NR \\
\hline $\begin{array}{l}\text { White Blood } \\
\text { Cell Count }\end{array}$ & $\mathrm{NR}$ & $N R$ & $1 / 120$ of baseline & High & $\mathrm{NR}$ \\
\hline $\begin{array}{l}\text { PAW } \\
\text { Classification }\end{array}$ & NR & $\mathrm{NR}$ & P3-B & NR & NR \\
\hline
\end{tabular}

\section{TABLE 2: PRP preparation}

NR (Not Recorded); PAW classification (classification system for PRP that incorporates platelet concentration, activation method, and white blood cell count); PRP: Platelet-Rich Plasma

VAS decreased by $26.4 \mathrm{~mm}$ at six months following intradiscal PRP injection (Table $3 ; \mathrm{p}<0.01$ ). However, only two studies (32 patients) reported individual data to allow a direct comparison of the change in VAS with previously reported MCID, SCB, and PASS. Of the two studies, only 19 patients (59.4\%) met MCID and 12 patients (37.5\%) met SCB and PASS. 


\section{Cureus}

\begin{tabular}{|c|c|c|c|c|c|c|}
\hline Study & & $\begin{array}{l}\text { Tuakli et al. } 2016 \\
\text { [31] }\end{array}$ & $\begin{array}{l}\text { Comella et al. } 2017 \\
{[32]}\end{array}$ & $\begin{array}{l}\text { Akeda et al. } 2017 \\
\text { [33] }\end{array}$ & $\begin{array}{l}\text { Levi et al. } 2016 \\
\text { [34] }\end{array}$ & $\begin{array}{l}\text { Bhatia et al. } 2016 \\
\text { [35] }\end{array}$ \\
\hline \multirow{2}{*}{ FRI } & Baseline & $51.47+15.62$ & NR & NR & NR & NR \\
\hline & $\begin{array}{l}\text { Final } \\
F / U\end{array}$ & $33.98+20.35$ & $N R$ & NR & NR & NR \\
\hline \multirow{2}{*}{ SF-36 Pain } & Baseline & $43.28+21.11$ & NR & NR & NR & NR \\
\hline & $\begin{array}{l}\text { Final } \\
\text { F/U }\end{array}$ & $67.79+23.51$ & NR & NR & NR & NR \\
\hline \multirow{2}{*}{$\begin{array}{l}\text { SF-36 Physical } \\
\text { Function }\end{array}$} & Baseline & $56.40+18.52$ & NR & NR & NR & NR \\
\hline & $\begin{array}{l}\text { Final } \\
\text { F/U }\end{array}$ & $73.20+19.38$ & $\mathrm{NR}$ & NR & NR & NR \\
\hline \multirow{2}{*}{ VAS } & Baseline & $79.8+15.6$ & 56 & $75+13$ & $66.0+12.2$ & $61.0+12.0$ \\
\hline & $\begin{array}{l}\text { Final } \\
\text { F/U }\end{array}$ & $58.2+23.3$ & 36 & $29+28$ & $41.4+27.0$ & $37.0+6.7$ \\
\hline \multirow{2}{*}{ PPI } & Baseline & NR & 2.6 & NR & NR & NR \\
\hline & $\begin{array}{l}\text { Final } \\
\text { F/U }\end{array}$ & $N R$ & 1.8 & NR & NR & NR \\
\hline \multirow{2}{*}{ ODI } & Baseline & NR & NR & NR & $31.0+9.8$ & NR \\
\hline & $\begin{array}{l}\text { Final } \\
\text { F/U }\end{array}$ & NR & $N R$ & NR & $23.5+16.2$ & $N R$ \\
\hline \multirow{2}{*}{ RDQ } & Baseline & NR & NR & $12.6+4.1$ & NR & NR \\
\hline & F/U & $N R$ & NR & $2.8+3.9$ & NR & NR \\
\hline \multirow{2}{*}{ MODQ } & Baseline & NR & NR & NR & NR & $49.2+9.6$ \\
\hline & $\begin{array}{l}\text { Final } \\
\text { F/U }\end{array}$ & $N R$ & $N R$ & NR & $N R$ & $29.5+11.6$ \\
\hline \multicolumn{2}{|l|}{ Complications } & 0 & 0 & 2-LE paresthesias & 0 & 0 \\
\hline \multicolumn{2}{|l|}{ Re-Injection } & 0 & 0 & 0 & 1 & 0 \\
\hline
\end{tabular}

\section{TABLE 3: Individual Study Outcome Measures}

NR (Not Recorded); PRP (Platelet-Rich Plasma); F/U (Follow-Up); FRI (Functional Rating Index); SF-36 (36-item Short-Form Health Survey); VAS (Visual Analog Score); PPI (Present Pain Intensity); ODI (Oswestry Disability Index); RDQ (Roland-Morris Disability Questionnaire); MODQ (Modified Oswestry Disability Questionnaire); LE (Lower Extremity) 


\section{Cureus}

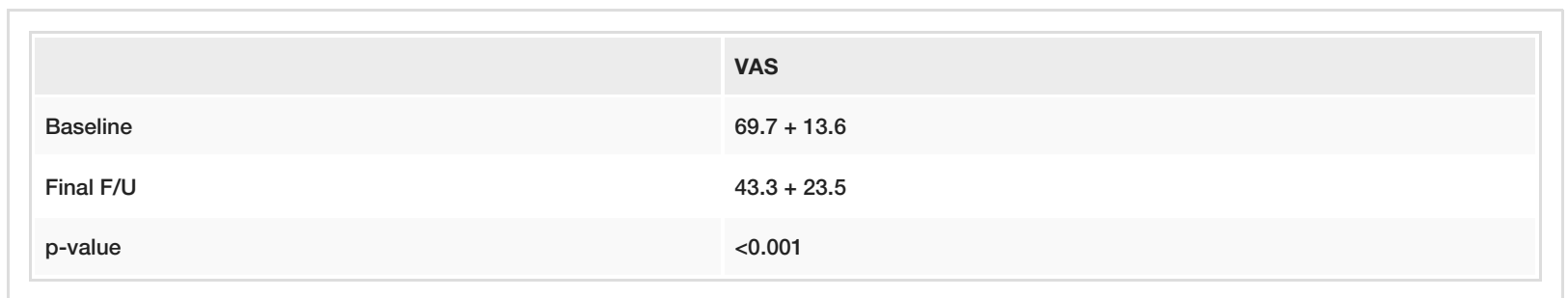

TABLE 4: Average study outcome measures included in best-evidence synthesis

VAS (Visual Analog Score); F/U (Follow-Up)

\section{Discussion}

It was determined that an intradiscal injection of PRP for DDD results in a statistically significant improvement in VAS. Although all reviewed studies presented statistical significance in the improvement of VAS after an intradiscal PRP injection for DDD (69.7 $\mathrm{mm}$ to $43.3 \mathrm{~mm}$; $\mathrm{p}<0.01$ ), no studies analyzed the clinical importance of outcome scores. Various studies have shown that a statistically significant score change in outcomes does not imply a clinically significant change [36-40]. Thus, measuring the MCID was introduced to determine the smallest difference in outcome score that patients found beneficial [41]. SCB is comparable to MCID but seeks to further develop a standard that better reflects the envisioned benefit of an intervention [42]. PASS is also a similar concept but instead represents the maximum amount of signs and symptoms beyond which patients consider themselves well [43]. Park et al. determined in a study of 105 patients with persistent LBP after lumbar surgery that the MCID and SCB for LBP VAS are $22.5 \mathrm{~mm}$ and 32.5 $\mathrm{mm}$, respectively [29]. Furthermore, Tuback et al. determined in a study of 330 ankylosing spondylitis patients that the PASS of LBP VAS is $33.5 \mathrm{~mm}$ [30]. Of the two reviewed studies that reported individual data, only 19 patients (59.4\%) met MCID and 12 patients (37.5\%) met SCB and PASS. This demonstrates that though the procedure results in statistically significant improvement, a large portion of the patients does not achieve a clinically meaningful improvement in outcomes.

All studies analyzed utilized an intradiscal injection of PRP to treat both the symptoms and the progression of disc degeneration in DDD. One of the analyzed studies by Comella et al. also utilized stromal vascular fraction (SVF) obtained from a mini-lipoaspirate procedure of fat tissue to be injected into the disc as a PRPSVF suspension [32]. The authors hypothesized that SVF, which is a mixture of growth factors and adiposederived stem cells (ADSCs), can be injected into the disc simultaneously with PRP to minimize inflammation while promoting healing. This study of 15 patients resulted in an average VAS decrease of $20.0 \mathrm{~mm}$ at the six-month follow-up with no adverse effects, which was neither superior nor inferior to other studies that utilized PRP alone.

Numerous types of PRP systems exist, with varying leukocyte, platelet, and growth factor concentrations. Leukocytes consist of neutrophils, eosinophils, basophils, lymphocytes, and monocytes, which are responsible for providing an acute and chronic inflammatory response against foreign invaders. Studies comparing leukocyte-rich and leukocyte-poor PRP have demonstrated a significantly higher inflammatory response and cell death seen with leukocyte-rich PRP [44-45]. Of the studies included in the review, Levi et al. used leukocyte-rich PRP, which showed a significant decrease in VAS (24.6 mm) at the six-month followup [34]. Akeda et al. used leukocyte-poor PRP and reported a larger decrease in VAS (43.0 mm) at the sixmonth follow-up [33]. However, this review was unable to develop conclusions regarding outcome differences in the use of leukocyte-rich versus leukocyte-poor PRP, as none of the reviewed studies directly compared the use of these formulations.

Complication and re-injection rates after intradiscal PRP injection were low. The re-injection rate in this study was $1.1 \%$. Furthermore, besides the $2.2 \%$ incidence of transient paresthesia post-injection, there were no reported adverse effects compared to the higher rates of complications with surgery such as infection, hematomas, thromboembolic events, and adjacent level disease. Overall, this study demonstrates that intradiscal injection of PRP for DDD leads to clinical improvement with low complication and re-injection rates. However, further higher-quality studies with randomized controlled trials are necessary to justify the use of PRP over more cost-effective treatment methods.

There are several limitations among the studies included in this review. Four of the five articles were level IV evidence, which limits the strength of the results [31-34]. None of the studies used a double-blinded approach producing potential bias. The average study methodological quality as assessed by the MCMS was fair. The assimilation of heterogeneous, low methodological-quality studies with VAS is a significant limitation. However, the authors minimized this as much as possible with strict study eligibility and inclusion criteria, despite the level IV evidence nature of the studies. Furthermore, the heterogeneity of outcome measures used among the studies limited the data analysis to one outcome measure. Additionally, MCID, SCB, and PASS are used to compare individual differences between preoperative and postoperative 
outcomes, and a majority of the reviewed studies reported means of patients and did not include individual statistics. Future studies can improve through designing a prospective comparative trial, increasing study size, and standardizing clinical outcome measures such as using VAS, ODI, numeric rating scale (NRS), and functional rating index (FRI) simultaneously. Another possible limitation of this review is that other relevant studies on this topic could have been excluded, despite conducting a systematic search.

\section{Conclusions}

Intradiscal injection of PRP for degenerative disc disease results in a statistically significant improvement in VAS with low re-injection and complication rates. Further randomized controlled studies that show a clinically relevant improvement in multiple outcome parameters are necessary to evaluate the true efficacy of this treatment.

\section{Additional Information \\ Disclosures}

Conflicts of interest: In compliance with the ICMJE uniform disclosure form, all authors declare the following: Payment/services info: All authors have declared that no financial support was received from any organization for the submitted work. Financial relationships: Joshua D. Harris declare(s) non-financial support from Arthroscopy. Editorial or governing board. Joshua D. Harris declare(s) non-financial support from American Orthopaedic Society for Sports Medicine. Board or committee member. Joshua D. Harris declare(s) non-financial support from AAOS. Board or committee member. Joshua D. Harris declare(s) nonfinancial support from Arthroscopy Association of North America. Board or committee member. Joshua D. Harris declare(s) a grant from DePuy, A Johnson \& Johnson Company. Research support. Joshua D. Harris declare(s) non-financial support from Frontiers In Surgery. Editorial or governing board. Joshua D. Harris declare(s) personal fees from NIA Magellan. Paid consultant. Joshua D. Harris declare(s) personal fees from Ossur. Paid consultant; Paid presenter or speaker SLACK Incorporated: Publishing royalties, financial.

Joshua D. Harris declare(s) personal fees from Smith \& Nephew. Paid consultant; Paid presenter or speaker; Research support. Other relationships: All authors have declared that there are no other relationships or activities that could appear to have influenced the submitted work.

\section{References}

1. Andersson GB: Epidemiological features of chronic low-back pain . Lancet. 1999, 354:581-585. 10.1016/S0140-6736(99)01312-4

2. Frank JW, Brooker AS, DeMaio SE, et al.: Disability resulting from occupational low back pain. Part I: What do we know about primary prevention? A review of the scientific evidence on prevention before disability begins. Spine. 1996, 21:2908-2917. 10.1097/00007632-199612150-00024

3. Deyo RA, Phillips WR: Low back pain. A primary care challenge . Spine. 1996, 21:2826-2832. 10.1097/00007632-199612150-00003

4. Schwarzer AC, Aprill CN, Derby R, Fortin J, Kine G, Bogduk N: The prevalence and clinical features of internal disc disruption in patients with chronic low back pain. Spine. 1995, 20:1878-1883. 10.1097/00007632-199509000-00007

5. Croft PR, Macfarlane GJ, Papageorgiou AC, Thomas E, Silman AJ: Outcome of low back pain in general practice: a prospective study. BMJ. 1998, 316:1356. 10.1136/bmj.316.7141.1356

6. Pengel LH, Herbert RD, Maher CG, Refshauge KM: Acute low back pain: systematic review of its prognosis BMJ. 2003, 327:323. 10.1136/bmj.327.7410.323

7. Vroomen PC, de Krom MC, Slofstra PD, Knottnerus JA: Conservative treatment of sciatica: a systematic review. J Spinal Disord. 2000, 13:463-469. 10.1097/00002517-200012000-00001

8. Luijsterburg PA, Verhagen AP, Ostelo RW, van Os TA, Peul WC, Koes BW: Effectiveness of conservative treatments for the lumbosacral radicular syndrome: a systematic review. Eur Spine J. 2007, 16:881-899. 10.1007/s00586-007-0367-1

9. Turner JA, Ersek M, Herron L, Haselkorn J, Kent D, Ciol MA, Deyo RA: Patient outcomes after lumbar spinal fusions. JAMA. 1992, 268:907-911. 10.1001/jama.1992.03490070089049

10. Deyo RA, Cherkin DC, Loeser JD, Bigos SJ, Ciol MA: Morbidity and mortality in association with operations on the lumbar spine. The influence of age, diagnosis and procedure. J Bone Joint Surg Am. 1992, 74:536543.

11. Deyo RA, Mirza SK, Martin BI, Kreuter W, Goodman DC, Jarvik JG: Trends, major medical complications, and charges associated with surgery for lumbar spinal stenosis in older adults. JAMA. 2010, 303:1259-1265. 10.1001/jama.2010.338

12. Rajaee SS, Bae HW, Kanim LE, Delamarter RB: Spinal fusion in the United States: analysis of trends from 1998 to 2008. Spine. 2012, 37:67-76. 10.1097/BRS.0b013e31820cccfb

13. Mannion AF, Fekete TF, O'Riordan D, et al.: The assessment of complications after spine surgery: time for a paradigm shift?. Spine. 2013, 13:615-624. 10.1016/j.spinee.2013.01.047

14. Basso M, Caagnaro L, Zanirato A, Divano S, Formica C, Formica M, Felli L: What is the clinical evidence on regenerative medicine in intervertebral disc degeneration?. Musculoskelet Surg. 2017, 101:93-104. 10.1007/s12306-017-0462-3

15. Foster TE, Puskas BL, Mandelbaum BR, Gerhardt MB, Rodeo SA: Platelet-rich plasma: from basic science to clinical applications. Am J Sports Med. 2009, 37:2259-2272. 10.1177/0363546509349921

16. Kajikawa Y, Morihara T, Sakamoto H, et al.: Platelet-rich plasma enhances the initial mobilization of circulation-derived cells for tendon healing. J Cell Physiol. 2008, 215:837-845. 10.1002/jcp.21368

17. Kasemkijwattana C, Menetrey J, Bosch P, et al.: Use of growth factors to improve muscle healing after strain 
injury. Clin Orthop Relat Res. 2000, 370:272-285. 10.1097/00003086-200001000-00028

18. Roberts S, Evans H, Trivedi J, Menage J: Histology and pathology of the human intervertebral disc . J Bone Joint Surg Am. 2006, 88:10-14.

19. Kabiri A, Esfandiari E, Esmaeili A, Hashemibeni B, Pourazar A, Mardani M: Platelet-rich plasma application in chondrogenesis. Adv Biomed Res. 2014, 3:138. 10.4103/2277-9175.135156

20. Van Buul GM, Koevoet WL, Kops N, et al.: Platelet-rich plasma releasate inhibits inflammatory processes in osteoarthritic chondrocytes. Am J Sports Med. 2011, 39:2362-2370. 10.1177/0363546511419278

21. Bendinelli P, Matteucci E, Dogliotti G, Corsi MM, Banfi G, Maroni P, Desiderio MA: Molecular basis of antiinflammatory action of platelet-rich plasma on human chondrocytes: mechanisms of NF-kappa B inhibition via HGF. J Cell Physiol. 2010, 225:757-766. 10.1002/jcp.22274

22. Moher D, Liberati A, Tetzlaff J, Altman DG, the PRISMA Group: Preferred reporting items for systematic reviews and meta-analyses: the PRISMA Statement. PLoS Med. 2009, 6:1000097. 10.1371/journal.pmed.1000097

23. The 2011 Oxford CEBM evidence levels of evidence (introductory document) . (2011). https://www.cebm.net/2011/06/2011-oxford-cebm-levels-evidence-introductory-document/.

24. Harris JD, Quatman CE, Manring MM, Siston RA, Flanigan DC: How to write a systematic review. Am J Sports Med. 2014, 42:2761-2768. 10.1177/0363546513497567

25. Coleman B, Khan K, Maffulli N, Cook J, Wark JD: Studies of surgical outcome after patellar tendinopathy: clinical significance of methodological deficiencies and guidelines for future studies. Scand J Med Sci Sports. 2000, 10:2-11. 10.1034/j.1600-0838.2000.010001002.x

26. Ebell MH, Siwek J, Weiss BD, Woolf SH, Susman J, Ewigman B, Bowman M: Strength of Recommendation Taxonomy (SORT): a patient-centered approach to grading evidence in the medical literature. Am Fam Physician. 2004, 69:549-557.

27. GRADE Working Group. (2000). Accessed: April 20, 2020: https://www.gradeworkinggroup.org/.

28. Slavin RE: Best evidence synthesis: an intelligent alternative to meta-analysis. J Clin Epidemiol. 1995, 48:918. 10.1016/0895-4356(94)00097-a

29. Park KB, Shin JS, Lee J, et al.: Minimum clinically important difference and substantial clinical benefit in pain, functional and quality of life scales in failed back surgery syndrome patients. Spine. 2017, 42:474-481. 10.1097/BRS.0000000000001950

30. Tuback F, Pham T, Skomsvoll JF, et al.: Stability of the patient acceptable symptomatic state over time in outcome criteria in ankylosing spondylitis. Arthritis Rheum. 2006, 55:960-963. 10.1002/art.22342

31. Tuakli-Wosornu YA, Terry A, Boachie-Adjei K, et al.: Lumbar intradiskal platelet-rich plasma (PRP) injections: a prospective, double-blind, randomized controlled study. Am J Phys Med Rehabil. 2016, 8:1-10. 10.1016/j.pmrj.2015.08.010

32. Comella K, Silbert R, Parlo M: Effects of the intradiscal implantation of stromal vascular fraction plus platelet rich plasma in patients with degenerative disc disease. J Transl Med. 2017, 15:12. 10.1186/s12967016-1109-0

33. Akeda K, Ohishi K, Masuda K, et al.: Intradiscal injection of autologous platelet-rich plasma releasate to treat discogenic low back pain: a preliminary clinical trial. Asian Spine J. 2017, 11:380-389. 10.4184/asj.2017.11.3.380

34. Levi D, Horn S, Tyszko S, Levin J, Hecht-Leavitt C, Walko E: Intradiscal platelet-rich plasma injection for chronic discogenic low back pain: preliminary results from a prospective trial. Pain Medicine. 2016, 17:10101022. 10.1093/pm/pnv053

35. Bhatia R, Chopra G: Efficacy of platelet rich plasma via lumbar epidural route in chronic prolapsed intervertebral disc patients-a pilot study. J Clin Diag Res. 2016, 10:5-7. 10.7860/JCDR/2016/21863.8482

36. Beaton DE: Understanding the relevance of measured change through studies of responsiveness. Spine. 2000, 25:3192-3199. 10.1097/00007632-200012150-00015

37. Bombardier C, Kerr MS, Shannon HS, Frank JW: A guide to interpreting epidemiologic studies on the etiology of back pain. Spine. 1994, 19:2047S-2056S. 10.1097/00007632-199409151-00006

38. Deyo RA, Patrick DL: The significance of treatment effects: the clinical perspective . Med Care. 1995, 33:286291.

39. Deyo RA, Diehr P, Patrick DL: Reproducibility and responsiveness of health status measures statistics and strategies for evaluation. Control Clin Trials. 1991, 12:142-158. 10.1016/s0197-2456(05)80019-4

40. Epstein RS: Responsiveness in quality-of-life assessment: nomenclature, determinants, and clinical applications. Med Care. 2000, 38:91-94.

41. Jaeschke R, Singer J, Guyatt GH: Measurement of health status. Ascertaining the minimal clinically important difference. Control Clin Trials. 1989, 10:407-415. 10.1016/0197-2456(89)90005-6

42. Glassman SD, Copay AG, Berven SH, Polly DW, Subach BR, Carreon LY: Defining substantial clinical benefit following lumbar spine arthrodesis. J Bone Joint Surg Am. 2008, 90:1839-1847. 10.2106/JBJS.G.01095

43. Tashjian RZ, Deloach J, Porucznik CA, Powell AP: Minimally clinically important differences (MCID) and patient acceptable symptomatic state (PASS) for visual analog scales (VAS) measuring pain in patients treated for rotator cuff disease. J Shoulder Elbow Surg. 2009, 18:927-932. 10.1016/j.jse.2009.03.021

44. Dragoo JL, Braun HJ, Durham JL, Ridley BA, Odegaard JI, Luong R, Arnoczky SP: Comparison of the acute inflammatory response of two commercial platelet-rich plasma systems in healthy rabbit tendons. Am J Sports Med. 2012, 40:1274-1281. 10.1177/0363546512442334

45. Braun HJ, Kim HJ, Chu CR, Dragoo JL: The effect of platelet-rich plasma formulations and blood products on human synoviocytes: implications for intra-articular injury and therapy. Am J Sports Med. 2014, 42:12041210. $10.1177 / 0363546514525593$ 